\title{
Making the Case for Using Informational Text in Preschool Classrooms
}

\author{
Susan L. Massey \\ Department of Curriculum and Instruction, Western Illinois University-Quad Cities, Moline, USA \\ Email: SL-Massey2@wiu.edu
}

Received 18 February 2014; revised 18 March 2014; accepted 25 March 2014

Copyright (C) 2014 by author and Scientific Research Publishing Inc.

This work is licensed under the Creative Commons Attribution International License (CC BY). http://creativecommons.org/licenses/by/4.0/

c) (i) Open Access

\begin{abstract}
This article explores the use of informational text in preschool environments by reviewing the current literature related to the topic. While informational text is currently used on a limited basis in early childhood settings, the benefits of introducing young children to this genre through interactive shared reading or read-alouds can positively influence foundational literacy development. Through exposure to informational text, children enhance their vocabulary and language skills while developing conceptual background knowledge. Strong vocabulary and language skills are keys to the development of strong literacy skills upon entrance to formal schooling. Read-aloud routines scaffold the learning inherent in the language and literacy development resulting from interactions with informational text.
\end{abstract}

\section{Keywords}

\section{Preschool, Informational Text, Read-Aloud, Shared Reading}

\section{Introduction}

Informational text is a type of nonfiction in which "the primary purpose is to convey information about the natural or social world” (Duke \& Bennett-Armistead, 2003: p. 16). Informational text typically presents and describes attributes and/or characteristic events related to a topic, introduces relevant vocabulary, and uses realistic illustrations or photographs as well as a variety of text features and navigational aids (Duke \& Bennett-Armistead, 2003). While the merits of introducing preschoolers to informational text are beginning to be outlined in the literature and informational text is deemed appropriate for young children (Duke, 2003), the practice of implementation in early childhood settings remains limited. This review explores the literature related to the merits of informational text and best practices for implementation in early childhood classrooms.

Several studies have investigated the availability and use of informational text in preschool classrooms. Yopp 
and Yopp (2006) studied read-aloud practices in preschool through third-grade classrooms and discovered that of the books teachers read aloud to students, approximately $8 \%$ were classified as informational text. Looking specifically at the preschool classrooms in the study, $5 \%$ of the books read aloud were informational text. In a follow-up study, Yopp and Yopp (2012) discovered that science read-alouds outnumbered those in other content areas with $85 \%$ of selections addressing science topics related to animals, earth and space science, and engineering/technology. During first grade classroom observations, Duke (2000) found that an average of 3.6 minutes per day were spent with informational text. When investigating read-aloud practices of preschool teachers, Pentimonti and her colleagues (2010) discovered that approximately $4 \%$ of the books read aloud by preschool teacher research participants were expository and 13\% were mixed (included elements of both narrative and informational texts) while $82 \%$ were narrative. These percentages represent the paucity of informational text currently part of the typical preschool literacy curriculum and practice.

A joint position statement by the International Reading Association and the National Association for the Education of Young Children issued in 1998 states, "children need to be exposed to vocabulary from a wide variety of genres, including informational texts as well as narratives" (National Association for the Education of Young Children, 1998: p. 34). The recommendation for balancing text types (narrative texts and informational texts) in the Common Core State Standards for kindergarten and primary grades is an equal balance of narrative and informational text structure for classroom use (National Governors Association Center for Best Practices, Council of Chief State School Officers, 2010). The existing research suggests that despite a growing awareness of the benefits of informational text as an instructional tool for young children, few early childhood professionals engage in reading informational text to their early childhood students.

Although the National Association for the Education of Young Children (NAEYC) cautioned against a blanket adaptation and adoption of Common Core State Standards in early childhood standards (National Association for the Education of Young Children, 2012), some states are beginning to include standards related to inclusion of informational text in preschool literacy standards using language such as "retell details about main topics in nonfiction books," "demonstrate interest and understanding of informational text," "ask and answer questions about details in nonfiction books," (Illinois Early Learning and Development Standards, 2013) and "demonstrate knowledge of informational text through labeling, describing, playing, and creating” (California Preschool Learning Standards, 2008). While NAEYC issued cautions, the organization also noted the opportunities inherent in including some aspects of Common Core State Standards in early childhood if issues of developmental appropriateness are considered (NAEYC, 2012).

\section{Benefits of Informational Text in Preschool Settings}

The benefits of using informational text with preschool students relate to enhanced (a) content area knowledge and vocabulary, (b) language skills, (c) knowledge about informational text structures and text features, and (d) reading interest and engagement (Cummins \& Stallmeyer-Gerard, 2011; Pentimonti, Zucker, Justice, \& Kaderavek, 2010). According to McGinty and Justice (2010), developing a language-rich classroom is paramount to quality preschool education. Language instructional targets evident in a language-rich classroom include instruction promoting vocabulary development and promoting complexity of child talk through explicit teaching, using appropriate questioning, and expanding children's attempts at language (McGinty \& Justice, 2010). The inclusion of informational text in preschool classrooms sets the stage for creating a language-rich classroom. Teachers bear the responsibility of presenting and scaffolding informational text to assist students in developing language and literacy skills (Frey \& Fisher, 2013).

\section{Content Area Knowledge and Vocabulary}

Building background knowledge and developing conceptual networks are crucial elements in preschoolers' literacy development (Neuman, 2001; Pollard-Durodola, Gonzalez, Simmons, Davis, Simmons, \& Nava-Walichowski, 2011). Large gaps in vocabulary knowledge beginning in the preschool years have been documented in the literature (e.g., Hart \& Risley, 1995; Stahl \& Stahl, 2009) and limited vocabulary has a negative impact on children's literacy skill and development as children progress to elementary school. In a content analysis of preschool curriculum, Neuman and Dwyer (2009) found a lack of instructional support for vocabulary development in the teacher manuals and little attention to teaching conceptual vocabulary in the materials. Preschool years are a critical period for vocabulary and language growth (Powell \& Diamond, 2012). It is hypothesized that children 
develop semantic conceptual networks by understanding relationships between new words and their connected concepts (Beckage, Smith, \& Hills, 2011). Additionally, young children learn vocabulary through meaningful and interactive contexts (Harris, Golinkoff, \& Hirsh-Pasek, 2011). Using a shared book reading approach, researchers described how a preschool teacher integrated vocabulary instruction that progressively built children's lexical networks (Pollard-Durodola, Gonzalez, Simmons, Davis, Simmons, \& Nava-Walichowski, 2011). The case study teacher immersed her preschool students by reading a sequence of informational books centered on social studies topics during two-week units. Through this immersion, students had multiple exposures to the content vocabulary and concepts related to the theme through book reading and extension activities. Opportunities to talk about connections between words and concepts were included in the instruction. The goal was to build lexical networks of connected vocabulary and concepts in the children's brains. Results of the study indicated positive gains in children's expressive and receptive vocabulary attributed to the book sharing and targeted conversations to build conceptual relationships.

\section{Language Skills}

As part of an interactive read aloud using informational text, teachers have the opportunity to engage children in conversations using abstract language and further develop their oral language competencies. Key components of preschool children's comprehensive oral language skills influence their developing literacy skills (Cunningham \& Zibulsky, 2011). Through book reading and conversations with adults, preschool children develop knowledge of grammar and syntax in addition to vocabulary (Bowyer-Crane et al., 2008). When preschool students are engaged in multiple exposures and multiple experiences using language, they are better able to develop conceptual understandings necessary for comprehension (Massey, 2013; Neuman \& Dwyer, 2009). In a study comparing parents' read aloud discussions using narrative text and expository text with their preschool children, robust differences in the complexity of the parent-child conversations were revealed (Price, Van Kleeck, \& Huberty, 2009). The parent-child interactions focused on expository text were longer in duration and included more child utterances and higher level utterances when compared to interactions during narrative book reading. Children were exposed to higher levels of talk in terms of parents labeling rare objects, parents' engagement in response and feedback to child's utterances, and a greater variety of comments and questions used throughout the reading sessions. While this study was conducted with preschoolers and their parents, similar results may be found when investigating preschool teachers and children.

\section{Knowledge about Text Structure and Text Features}

The language and structure of informational text differs from narrative text. When presenting informational text in a shared reading format, early childhood teachers are provided the opportunity to demonstrate and explain text structures such as compare/contrast, sequence, cause/effect, description, and problem/solution to their students (Hall \& Sabey, 2007; Read, Reutzel, \& Fawson, 2008). Exposing children to informational text structure in the preschool years may mitigate some of the difficulty children encounter with expository text structure in elementary school (Pentimonti et al., 2010; Sanacore \& Palumbo, 2009; Santoro, Chard, Howard, \& Baker, 2008). Preschool teachers can read aloud books with well-structured text structures and scaffold children's understanding of the structures through thinking aloud the comprehension processes.

Much of the information in informational text is conveyed through the photographs, illustrations, and graphic features (Duke, 2013). When using informational text in preschool settings, teachers draw children's attention to the print and graphic text features such as headings, captions, photographs, labels, diagrams, charts, and cross sections. Preschool teachers can point out and discuss the text features contained in the book to further enhance children's vocabulary and comprehension of the topic.

\section{Reading Interest and Engagement}

Young children have a natural interest and are inquisitive about the world around them (Duke, 2003). Informational text includes topics of interest to young children as they learn about their scientific and social world. The use of informational text in preschool settings can be a motivator for developing interest in literacy and may be especially important for motivating young boys (Senn, 2012). Research indicates that boys often prefer informational text rather than narrative text from an early age partly due to biological and neurological functioning 
(Senn, 2012). Fiction texts used in early childhood settings often focus on emotions and language skills in which boys' brains are developmentally less advanced; therefore, boys' literacy interests often are closely aligned with informational text as they yearn to understand the world around them (Senn, 2012). In a study of kindergarten boys and girls, Correia (2011) determined that kindergarten children participating in the study revealed a strong interest in informational text as evidenced by their library book choices, classroom book talks, and written responses to prompts probing book preferences. Including informational text in preschool settings enhances children's engagement with text as they learn about their world.

\section{Read-Aloud Routines}

When presenting an informational text to preschool children, a number of shared book reading routines are recommended to engage young children in the experience (Pinnell \& Fountas, 2011). Much of the content is conveyed through the photographs and print in informational text; therefore, children must be able to clearly see the book when the teacher engages them in a shared reading experience. As the teacher introduces the content of the book, utilizing props related to the book assists children in identifying and understanding the concepts and vocabulary contained in the material. Also necessary in the book introduction is a focus on previewing the book and drawing attention to images or features of the book in order to pique the children's interest or prompt their thinking about the topic (Yopp \& Yopp, 2012). For optimal interaction, it is important for teachers to invite conversations during the reading process through routines such as "turn and talk" in which students respond to a question by turning and talking to a neighboring child during the reading experience. This routine allows every child to use oral language to respond to a comment or question posed by the teacher. During the shared reading experience, teachers should also carefully point out important text features and model their thinking in identifying text structures such as compare/contrast, problem/solution, sequence, etc. In addition, follow up discussions using the vocabulary of the text is important. These discussions serve to further connect children's previous knowledge and experiences to the new information gleaned from the text (Yopp \& Yopp, 2012).

The pairing of activities related to the theme also serves to enhance children's language use and concept development. For example, extending the informational text reading into guided play provides children an opportunity to engage in continued exposure to the vocabulary, language, and content of the book (Massey, 2013; Pollard-Durodola, Gonzalez, Simmons, Kwok, Taylor, Davis, Kim, \& Simmons, 2011). The teacher's role in guided play is to interact and model with students using instructional tools, props, experiments and conversation (Saracho, 2004). Using informational text combined with active play and discussions has revealed positive gains for children's transference and application of knowledge and language (Gelman, Ware, Manczak, \& Graham, 2012; Mantzicopoulos \& Patrick, 2011).

\section{Conclusion}

With careful consideration when choosing appropriate informational text for preschool children and careful instructional planning, preschool teachers and caregivers can expand early childhood children's vocabulary, content knowledge, language skills, and knowledge of expository text structure through professionally executed read aloud lessons (Dwyer \& Neuman, 2008). Informational text serves to assist children in their conceptual development and encourages them to engage in higher order thinking. Informational text paired with theme related fiction text, extension activities, and adult-child conversation serves to address preschool learning standards through a targeted exploration of the natural and social world.

\section{References}

Beckage, N., Smith, L., \& Hills, T. (2011). Small Worlds and Semantic Network Growth in Typical and Late Talkers. PLoS One, 6, e19348. http://dx.doi.org/10.1371/journal.pone.0019348

Bowyer-Crane, C., Snowling, M. J., Duff, F. J., Fieldsend, E., Carroll, J. M., Miles, J., et al. (2008). Improving Early Language and Literacy Skills: Differential Effects of an Oral Language versus a Phonology with Reading Intervention. Journal of Child Psychology and Psychiatry, 49, 422-432. http://dx.doi.org/10.1111/j.1469-7610.2007.01849.x

California Preschool Learning Foundations Volume 1 (2008). http://www.cde.ca.gov/sp/cd/re/documents/preschoollf.pdf

Correia, M. P. (2011). Fiction vs. Informational Texts: Which Will Kindergartners Choose? Young Children, 66, $100-104$.

Cummins, S., \& Stallmeyer-Gerard, C. (2011). Teaching for Synthesis of Informational Texts with Read-Alouds. The Read- 
ing Teacher, 64, 394-405, http://dx.doi.org/10.1598/RT.64.6.1

Cunningham, A. E., \& Zibulsky, J. (2011). Tell Me a Story: Examining the Benefits of Shared Reading. In S. B. Neuman, \& D. K. Dickinson (Eds.), Handbook of Early Literacy Research (Vol. 3, pp. 396-411). New York: The Guilford Press.

Duke, N. K. (2000). 3.6 Minutes per Day: The Scarcity of Informational Texts in First Grade. Reading Research Quarterly, 35, 202-224. http://dx.doi.org/10.1598/RRQ.35.2.1

Duke, N. K. (2003). Information Books in Early Childhood. Young Children, 58, 14-20.

Duke, N. K. (2013). Starting out: Practices to Use in K-3. Educational Leadership, 71, 40-44.

Duke, N. K., \& Bennett-Armistead, V. S. (2003). Reading and Writing Informational Text in the Primary Grades: ResearchBased Practices. New York: Scholastic Teaching Resources.

Dwyer, J., \& Neuman, S. B. (2008). Selecting Books for Children Birth through Four: A Developmental Approach. Early Childhood Education Journal, 35, 489-494. http://dx.doi.org/10.1007/s10643-008-0236-5

Frey, N., \& Fisher, D. (2013). Points of Entry: Students Need Skilled Guides to Help Them Master Complex Informational Texts. Educational Leadership, 71, 34-38.

Gelman, S. A., Ware, E. A., Manczak, E. M., \& Graham, S. A. (2012). Children’s Sensitivity to the Knowledge in Pedagogical and Nonpedagogical Contexts. Developmental Psychology, 49, 491-504.

Hall, K. M., \& Sabey, B. L. (2007). Focus on the Facts: Using Informational Texts Effectively in Early Elementary Classrooms. Early Childhood Education Journal, 35, 261-268. http://dx.doi.org/10.1007/s10643-007-0187-2

Harris, J., Golinkoff, R. M., \& Hirsh-Pasek, K. (2011). Lessons from the Crib for the Classroom: How Children Really Learn Vocabulary. In S. B. Neuman, \& D. K Dickinson (Eds.), Handbook of Early Literacy Research (3rd ed., pp. 49-65). New York: The Guilford Press.

Hart, B., \& Risley, T. R. (1995). Meaningful Differences in the Everyday Experience of Young American Children. Baltimore, MD: Paul H. Brookes Publishing Company.

Illinois Early Learning and Development Standards (2013). http://www.isbe.state.il.us/earlychi/pdf/early_learning_standards.pdf

Mantzicopoulos, P., \& Patrick, H. (2011). Reading Picture Books and Learning Science: Engaging Young Children with Informational Text. Theory into Practice, 50, 269-276. http://dx.doi.org/10.1080/00405841.2011.607372

Massey, S. L. (2013). From the Reading Rug to the Play Center: Enhancing Vocabulary and Comprehensive Language Skills by Connecting Storybook Reading and Guided Play. Early Childhood Education Journal, 41, 125-131. http://dx.doi.org/10.1007/s10643-012-0524-y

McGinty, A. S., \& Justice, L. M. (2010). Language Facilitation in the Preschool Classroom: Rationale, Goals, and Strategies. In M. C. McKenna, S. Walpole, \& K. Conradi (Eds.), Promoting Early Reading: Research, Resources, and Best Practices (pp. 9-36). New York: The Guilford Press.

National Association for the Education of Young Children (1998). Learning to Read and Write: Developmentally Appropriate Practices for Young Children. Young Children, 53, 30-46.

National Association for the Education of Young Children (2012). The Common Core State Standards: Caution and Opportunity for Early Childhood Education. https://www.naeyc.org/files/naeyc/11_CommonCore1_2A_rv2.pdf

National Governors Association Center for Best Practices, Council of Chief State School Officers (2010). Common Core State Standards for English Language Arts. Washington, DC: National Governors Association Center for Best Practices, Council of Chief State School Officers.

Neuman, S. B. (2001). The Role of Knowledge in Early Literacy. Reading Research Quarterly, 36, 468-475. http://dx.doi.org/10.1598/RRQ.36.4.6

Neuman, S. B., \& Dwyer, J. (2009). Missing in Action: Vocabulary Instruction in Pre-k. The Reading Teacher, 62, $384-392$. http://dx.doi.org/10.1598/RT.62.5.2

Pentimonti, J. M., Zucker, T. A., Justice, L. M., \& Kaderavek, J. N. (2010). Informational Text Use in Preschool Classroom Read-Alouds. The Reading Teacher, 63, 656-665. http://dx.doi.org/10.1598/RT.63.8.4

Pinnell, G. S., \& Fountas, I. C. (2011). Literacy Beginnings: A Prekindergarten Handbook. Portsmouth, NH: Heinemann.

Pollard-Durodola, S. D., Gonzalez, J. E., Simmons, D. C., Davis, M. J., Simmons, L., \& Nava-Walichowski, M. (2011). Using Knowledge Networks to Develop Preschoolers’ Content Vocabulary. The Reading Teacher, 64, 265-274.

http://dx.doi.org/10.1002/TRTR.01035

Pollard-Durodola, S. D., Gonzalez, J. E., Simmons, D. C., Kwok, O, Taylor, A. B., Davis, M. J., Kim, M., \& Simmons, L. (2011). The Effects of an Intensive Shared Book-Reading Intervention for Preschool Children at Risk for Vocabulary Delay. Exceptional Children, 77, 161-183.

Powell, D. R., \& Diamond, K. E. (2012). Promoting Early Literacy and Language Development. In R. C. Pianta, W. S. Bar- 
nett, L. M. Justice, \& S. M. Sheridan (Eds.), Handbook of Early Childhood Education (pp. 194-216). New York: The Guilford Press.

Price, L. H., Van Kleeck, A., \& Huberty, C. J. (2009). Talk during Book Sharing between Parents and Preschool Children: A Comparison between Storybook and Expository Book Conditions. Reading Research Quarterly, 44, 171-194. http://dx.doi.org/10.1598/RRQ.44.2.4

Read, S., Reutzel, D. R., \& Fawson, P. C. (2008). Do You Want to Know What I Learned? Using Informational Trade Books as Models to Teach Text Structure. Early Childhood Education Journal, 36, 213-219. http://dx.doi.org/10.1007/s10643-008-0273-0

Sanacore, J., \& Palumbo, A. (2009). Understanding the Fourth-Grade Slump: Our Point of View. The Educational Forum, 73, 67-74. http://dx.doi.org/10.1080/00131720802539648

Santoro, L. E., Chard, D. J., Howard, L., \& Baker, S. K. (2008). Making the Very Most of Classroom Read-Alouds to Promote Comprehension and Vocabulary. The Reading Teacher, 61, 396-408. http://dx.doi.org/10.1598/RT.61.5.4

Saracho, O. (2004). Supporting Literacy-Related Play: Roles for Teachers of Young Children. Early Childhood Education Journal, 31, 201-206. http://dx.doi.org/10.1023/B:ECEJ.0000012138.07501.44

Senn, N. (2012). Effective Approaches to Motivate and Engage Reluctant Boys in Literacy. The Reading Teacher, 66, 211220. http://dx.doi.org/10.1002/TRTR.01107

Stahl, S., \& Stahl, K. A. D. (2009). Word Wizards All! Teaching Word Meanings in Preschool and Primary Education. In M. F. Graves (Ed.), Essential Readings on Vocabulary Instruction (pp. 15-27). Newark, DE: International Reading Association.

Yopp, R. H., \& Yopp, H. K. (2006). Informational Text as Read-Alouds at School and Home. Journal of Literacy Research, 38, 37-51. http://dx.doi.org/10.1207/s15548430jlr3801_2

Yopp, R. H., \& Yopp, H. K. (2012). Young Children’s Limited and Narrow Exposure to Informational Text. The Reading Teacher, 65, 480-490. http://dx.doi.org/10.1002/TRTR.01072 